Research Article

\title{
Observations on fertile populations of two Porella (Porellaceae, Marchantiophyta) species from Kumaun Region in the Western Himalaya, India
}

\author{
Meena Rai ${ }^{1}$, Prateek Srivastava ${ }^{2}$ and Surendra N. Srivastava ${ }^{{ }^{* 1}}$ \\ ${ }^{1}$ Department of Botany, C.M.P. College, Allahabad 211 002, India \\ ${ }^{2}$ Amity Institute of Environmental Sciences, Amity University, Noida 201 303, India
}

Article history

Received: 8 March 2016

Accepted: 31 March 2016

Published: 16 April 2016

(c) Rai et al. (2016)

Special Section: New Frontiers in Cryptogamic Botany

Section Editor

Afroz Alam

\section{Publisher}

Horizon e-Publishing Group

Corresponding Author

Surendra N. Srivastava

$\bigotimes_{\text {sn bryo@yahoo.co.in }}$

\begin{abstract}
The unrecorded androecia and feebly described gynoecia in Indian specimens of two Porella species, namely, P. densifolia subsp. appendiculata (Steph.) S. Hatt. and P. campylophylla var. ptychantha (Mitt.) F. Shaheen \& S.C. Sriv., collected from Kumaun region in the state of Uttarakhand in Western Himalaya, are being described and compared besides observing variations in vegetative features of the plants.
\end{abstract}

Keywords

Porella; leafy liverwort; fertile specimens; Kumaun Region; Western Himalaya

Rai, M., P. Srivastava and S. N. Srivastava. 2016. Observations on fertile populations of two Porella (Porellaceae, Marchantiophyta) species from Kumaun Region in the Western Himalaya, India. Plant Science Today 3(2): 142-148. http://dx.doi.org/10.14719/pst.2016.3.2.205

\section{Introduction}

In course of survey of the liverwort flora of Kumaun Region in the State of Uttarakhand in Western Himalaya, we came across two profusely fertile Porella species, namely, $P$. densifolia subsp. appendiculata (Steph.) S. Hatt. and P. campylophylla var. ptychantha (Mitt.) F. Shaheen \& S.C. Sriv. during the winter months in 2014. It was heavily snowing for more than a week when we collected these specimens. While population of the former species was observed at Dhobi Ghat $\left(29^{\circ} 25^{\prime} 17.4^{\prime \prime} \mathrm{N}\right.$; $79^{\circ} 26^{\prime} 2.5^{\prime} \mathrm{E} ; 2031 \mathrm{~m}$ ), the population of latter species was noted at Mukteshwar $\left(29^{\circ} 28^{\prime} 29^{\prime \prime} \mathrm{N} ; 79^{\circ}\right.$ 38' 45.3"E; $2269 \mathrm{~m}$ ) - both localities in Nainital district. It is interesting to note that in our earlier collection tours made during summer and post rainy months of the year, we could find only the sterile specimens of the species, though from different localities in this region. In fact, the population of Porella, a dioecious genus, is seldom observed in a fertile state.

A perusal of literature showed that the two taxa are purely tropical and largely Himalayan. While P. densifolia subsp. appendiculata (Steph.) S. Hatt. in India (besides Nepal and China, see Hattori, 1966 and Bapna and Kachroo, 2000) is largely confined to Western Himalaya, the other taxon, namely, $P$. campylophylla var. ptychantha (Mitt.) F. Shaheen \& S.C.Sriv., is recorded both from Western and Eastern Himalaya (Singh and Singh, 2006). Kashyap (1932) in his monumental work on "Liverworts of Western Himalaya and Panjab Plain" has described the former species as Madotheca appendiculata Steph., yet their description lacks the 

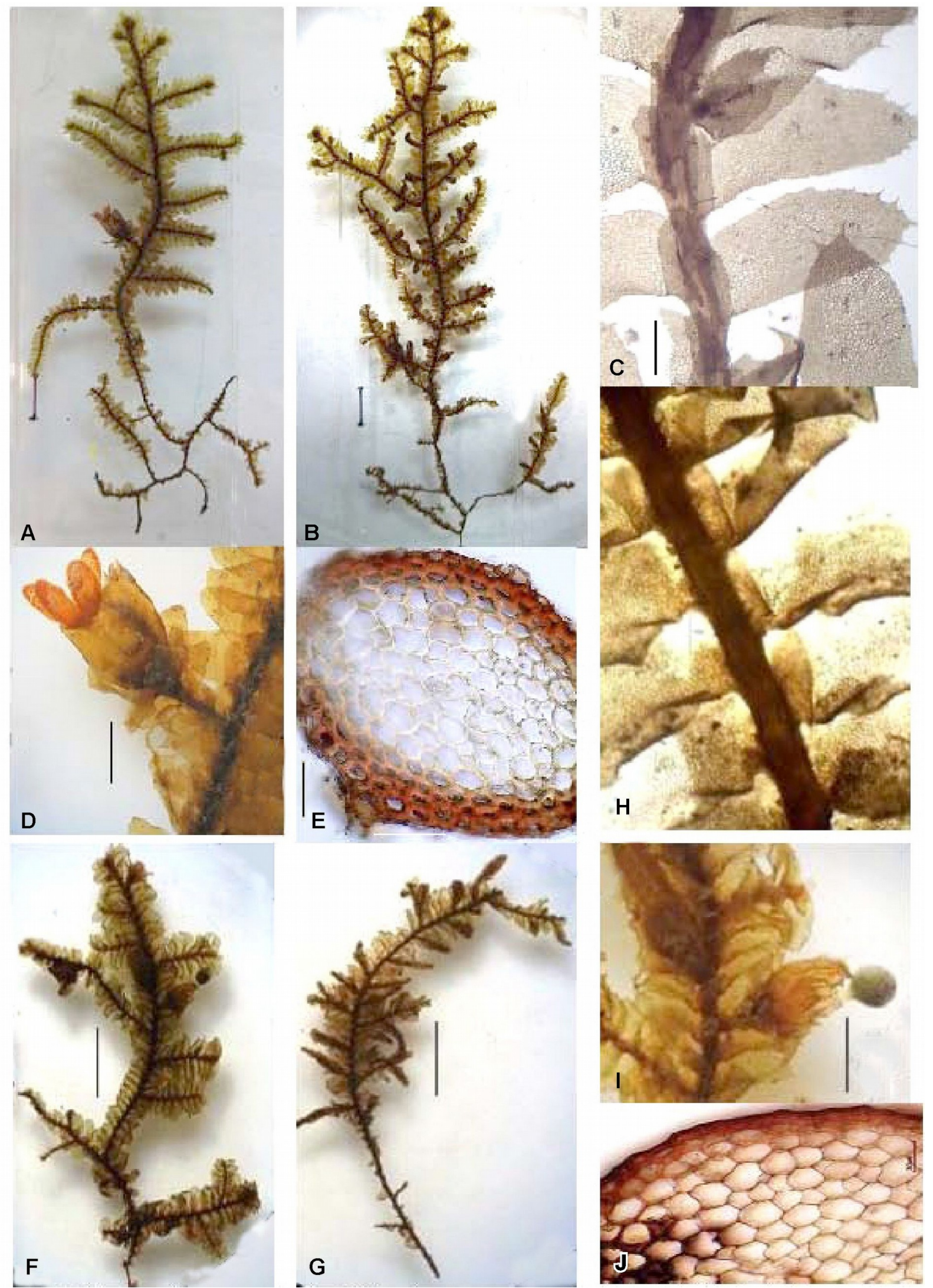

Plate 1: Figures A-E. Porella densifolia subsp. appendiculata (Steph.) S. Hatt. A. Female plant, ventral view; B. Male plant, ventral view; C. Part of the plant magnified, ventral view; D. Perianth with dehisced capsule; E. Stem, t.s. Figures F-J. Porella campylophylla var. ptychantha (Mitt.)F. Shaheen \& S. C. Sriv. F. Female plant, ventral view; G. Male plant, ventral view; $\mathbf{H}$. A part of the plant magnified, ventral view; I. Perianth with capsule; J. Stem, t.s. part only. (Bars: A, B, F, G = 8 mm; $\mathrm{D}, \mathrm{I}=2 \mathrm{~mm}$; $\mathrm{C}, \mathrm{E}, \mathrm{H}, \mathrm{J}=0.03 \mathrm{~mm}$ )

details of the androecia and those of the sex organs. So is the case with the description of the latter species by Shaheen and Srivastava (1989). In order to fill the gap of details of androecia and to provide additional information on gynoecia and sporophyte structures, an effort to describe the two species has been made. 


\section{Materials and methods}

The morphological studies of fresh specimens were made using Motic BA 210 Digital microscope. The slides of various parts of the plant including hand sections were mounted in glycerine jelly. The field photographs were taken by Olympus camera. All the specimens are deposited in Duthie Herbarium, Botany Department; University of Allahabad.

\section{Description}

\section{Porella densifolia subsp. appendiculata} (Steph.) S. Hatt.

Journ. Hattori Bot. Lab. 32:343 (1969); Madotheca appendiculata Steph., Spec. Hepat. 4:301-302 (1910); Kashyap, Liverw. of West. Him. And Panjab Plain Part II: 28-29 (1932); Porella appendiculata (Steph.) S. Hatt. in Hara, Flora E. Him.: 524 (1966).

\section{(Plate 1: Figures A - E and Plate 2: Figures A - N)}

Dioecious. Female plants larger and robust, more than $60 \mathrm{~mm}$ long and 4 to $6 \mathrm{~mm}$ wide with leaves, arising from rhizomatous axis, bipinnately branched, greenish brown to golden brown. Gynoecia on short lateral branches, 5 - $7 \mathrm{~mm}$ long, 1 - 4 per plant, generally in the lower region. Female bracts ovate oblong, $2.6-3.0 \mathrm{~mm}$ long and 1.6 - $1.8 \mathrm{~mm}$ wide, 2 - 3 pairs, margin undulate, apex toothed; female bracteole ovate, $1.6-1.8 \mathrm{~mm}$ long and $0.8-1.1 \mathrm{~mm}$ wide, apex dentate. Archegonia terminal, 3 to 8 per gynoecium,0.15 $0.7 \mathrm{~mm}$ long, various stages of developing sporogonia observed. Perianth large, $10-12 \mathrm{~mm}$ long and 9-11 mm wide, campanulate, free margin strongly frilled and dentate. Capsule dehisced by 4 - valves.Male plants linear and less widespread, rhizomatous, up to $50 \mathrm{~mm}$ long and 3 - $4 \mathrm{~mm}$ wide with leaves, green brown to golden brown.Androecia numerous per plant, dark brown, arising from primary or secondary axes, $2.2-3.0 \mathrm{~mm}$ long. Male bracts in $6-9$ pairs, deeply concave, imbricate, each subtended by a single antheridium, male bracteoles $6-9$, present along the axis. Antheridia spherical,1.2 $-0.8 \mathrm{~mm}$, jacket 1-layered, stalk $0.6-0.7 \mathrm{~mm}$ long.Common features: Stem in cross section, $3-4$ layered cortex, cells smaller, thick walled, dark brown, 18 $\mathrm{x} 11 \mu \mathrm{m}$ surrounding the larger, transparent medullary cells, $24 \times 18 \mu \mathrm{m}$. Leaves imbricate; leaf - lobes ovate - oblong, $2.2-2.6 \mathrm{~mm}$ long and 1.3 $1.7 \mathrm{~mm}$ wide near base, almost horizontally spreading, the dorsal margin arched beyond the stem, the ventral margin nearly straight, apex apiculate, with $1-4$ additional teeth or rarely obtuse; marginal cells $14-17$ x 12 - $14 \mu \mathrm{m}$, walls thick, with little distinction of trigones, median cells $20-30 \times 20-25 \mu \mathrm{m}$, with triangular trigones, basal cells $30-45 \times 18-27 \mu \mathrm{m}$, trigones large, nodulose, more or less confluent; leaf - lobules nearly parallel, appressed to stem, undulate, 1.0 $1.2 \mathrm{~mm}$ long and $0.5-0.8 \mathrm{~mm}$ wide, apex obtuse, the base with lacinulate - toothed appendages, larger towards distal than proximal side; underleaves ovate, $1.2-1.6 \mathrm{~mm}$ long and $0.9-1.2$ $\mathrm{mm}$ wide, wider at base, apex often recurved, subtruncate or obtuse, lateral margins also narrowly recurved, the appendicules larger than those of leaf - lobules, decurrent on either side, the insertion line arching up on the stem.

Specimens examined: WHKN 140 L/14 (fertile), Dhobi Ghat, Nainital district in Kumaun region in the state of Uttarakhand in Western Himalaya, 26.02.2014, leg. S N Srivastava \& Meena Rai, det. S N Srivastava \& Meena Rai.WHKN 0264 L/15 (sterile), Munsyari, Pithoragarh district in Kumaun region in the state of Uttarakhand in Western Himalaya, 06.10.2015, leg. S N Srivastava \& Meena Rai, det. S N Srivastava \& Meena Rai

Habitat and Ecology: The species grows on the bark of oak tree, Quercus leucotrichophora A Camus. The most commonly associated mosses are Leptohymenium tenue (Hook.) Schwägr. Pterobryopsis acuminata (Hook.) M. Fleisch. and Meteorium buchanani (Brid.) Broth. and the liverwort Frullania ericoides in Nainital populations. In Munsyari populations the common associates are Ptychanthus striatus (Lehm. \& Lindenb.) Nees and Lopholejeunea sikkimensis Steph.

Distribution: China and Nepal. In India: Eastern Himalaya - Sikkim; Western Himalaya - Kashmir (Pahalgam); Kumaun (Nainital); Mussoorie; Dalhousie; Punjab Plain (Bapna and Kachroo, 2000).

\section{Type Locality: Mussoorie (Western Himalaya)}

\section{Porella campylophylla var. ptychantha(Mitt.)F. Shaheen \& S.C.Sriv.}

Geophytology 19 (1): 37 (1989); Madotheca ptychantha Mitt.Journ. Proc. Linn. Soc. London 5:108 (1861).As Porella ptychantha (Mitt.) S. Hatt., Journ. Hattori Bot. Lab. 34: 426 (1971).

\section{(Plate 1: Figures F - J and Plate 3: Figures A - Q)}

Dioecious. Female plants medium-sized, 30 - $45 \mathrm{~mm}$ long and $3.0-3.6 \mathrm{~mm}$ wide with leaves, deep green, bipinnately branched. Gynoecia developing on short lateral branches, $3.0-3.5 \mathrm{~mm}$ long and $0.8-1.1 \mathrm{~mm}$ wide. Female bracts in 1 pair, oblong ovate, $1.8-2.1 \mathrm{~mm}$ long and $1.0-1.2$ $\mathrm{mm}$ wide, undulate, apex dentate; female bracteole widely ovate oblong, $1.4-1.7 \mathrm{~mm}$ long and $0.7-0.9 \mathrm{~mm}$ wide, often trilobed, undulate. Perianth elliptic, $2.8-3.0 \mathrm{~mm}$ long and $1.7-1.9$ $\mathrm{mm}$ wide, pleuriplicate, plicaecrenulate, mouth surrounded by uniseriate but muticellular teeth. Capsule spherical, capsule wall $3-4$ layered, cells 


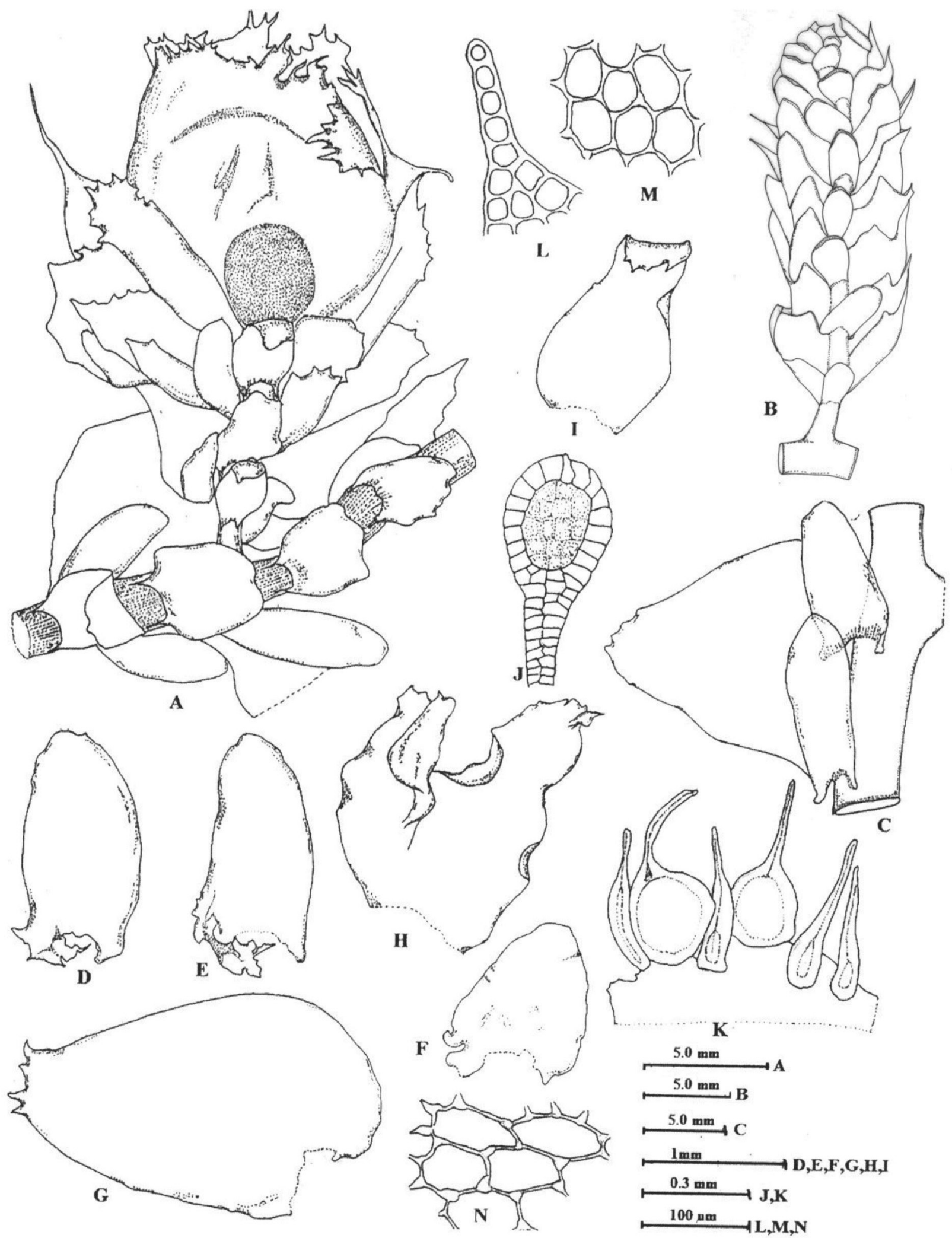

Plate 2: Porella densifolia subsp. appendiculata (Steph.) S. Hatt. (Figures: A-N). A. Part of the female plant with perianth, ventral view; B. Male branch, ventral view; $C$. Part of the plant showing attachment of the leaf-lobules (amphigastria removed), ventral view; D. \& E. Leaf-lobules; F. Amphigastrium; G. Leaf-lobe; H. Female bract; I. Female bracteole; J. Antheridium, l.s.; K.Apex of female branch showing developing sporophytes and unfertilised archegonia, l.s.; L. Tooth of the leaf-lobe; M. Median cells of the leaf-lobe; and, N. Basal cells of the leaf-lobe.

of the outermost layer with nodular trigonous thickenings, cells of inner layer with irregular thickenings on the walls. Spores $48-52 \mu \mathrm{m}$ in diameter, dark coloured, finely papillose. Elaters free, elongated, $570-620 \mu \mathrm{m}$ long and $0.70-0.85$ $\mu \mathrm{m}$ wide, occasionally branched, usually 2- rarely 3-spiralled. Male plants linear, without secondary vegetative branches, deep green, producing 

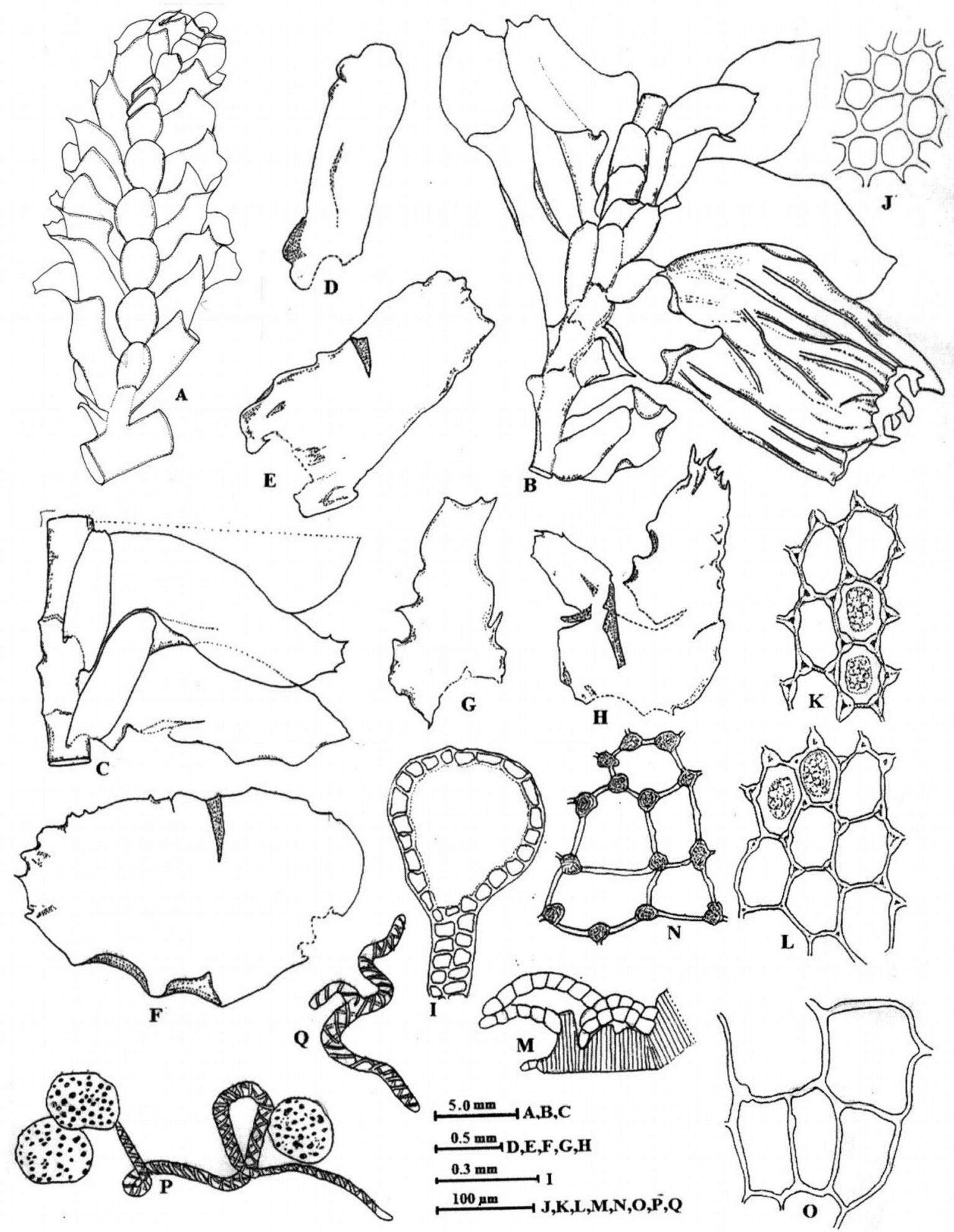

Plate 3: Porella campylophylla var. ptychantha (Mitt.) F. Shaheen \& S. C. Sriv. (Figures A-Q). A. Male branch, ventral view; B. Part of female plant with perianth, ventral view; C. Part of the stem showing attachments of leaf-lobules (amphigastria removed) on stem, ventral view; D. Leaf-lobule; E. Amphigastrium; F. Leaf-lobe; G. Female bracteole; H. Female bract; I. Antheridium, l.s. ; J. Upper cells of the leaf-lobe; K. Median cells of the leaf-lobe; L. Basal cells of the leaf-lobe; M. Perianth cells at mouth; $N$. Cells of outer layer of capsule wall; $\mathbf{O}$. Cells of inner layer of capsule wall; $P$. An elater with spores; and $Q$. A branched elater.

numerous androecia at right angles to the primary axis. Androecia $2.7-3.0 \mathrm{~mm}$ long and $0.8-1.0 \mathrm{~mm}$ wide, dark green to blackish. Male bracts in $8-12$ pairs, deeply concave, imbricate; male bracteoles 8 -12, present along the axis. Antheridia spherical to slightly oblong, $1.3 \times 1.1 \mathrm{~mm}$ in diameter, supported on a $0.4-0.5 \mathrm{~mm}$ long stalk. Common features: Stem in cross section, generally 2- or rarely 3- layered cortex, cortical cells smaller, 13 $21 \times 10-17 \mu \mathrm{m}$ thick walled, dark brown, 
surrounding the larger, trigonous, transparent medullary cells, 14 - 40 x 11 - $26 \mu \mathrm{m}$. Leaves imbricate; the leaf-lobe ovate-oblong, 1.9 to 2.3 $\mathrm{mm}$ long and 1.2 to $1.7 \mathrm{~mm}$ wide, apex subtruncate to obtuse, with $3-5$ blunt teeth, ventral margin partly recurved; leaf-lobe cells with distinct trigones, marginal cells 12 - 26 x 10 - 19 $\mu \mathrm{m}$, median cells $24-38 \times 15$ - $21 \mu \mathrm{m}$, basal cells 23 -48 x $20-30 \mu \mathrm{m}$ the leaf-lobule ligulate, 1.1 to 1.7 $\mathrm{mm}$ long and 0.35 to $0.50 \mathrm{~mm}$ wide, apex obtuse, with 1 or 2 teeth, base shortly recurved, apex obtuse; underleaves oblong, wider at base, 1.20 to $1.45 \mathrm{~mm}$ long and 0.85 to $1.30 \mathrm{~mm}$ wide, apex obtuse or ligulate, base longly decurrent, with strongly recurved lateral margin.

Specimens examined: WHKN 0217 L/14, Mukteshwar, Nainital district in Kumaun region in the state of Uttarakhand in Western Himalaya, 02.03.2014, leg.S N Srivastava \& MeenaRai, det. S N Srivastava \& Meena Rai. WHKP 0195 L/15 \& 0196 L/14, Patal Bhuvaneshwar, Pithoragarh district in Kumaun region in the state of Uttarakhand in Western Himalaya, 01.03.2014, leg. S N Srivastava \& MeenaRai, det. S N Srivastava \& MeenaRai.

Habitat and Ecology: The species grows on the bark of oak tree, Quercus leucotrichophora A Camus. associated with some pleurocarpus mosses in very moist conditions.

Distribution: Endemic to Himalaya. Eastern Himalaya - Kurseong, Pynursala; Western Himalaya - Loharkhet. (Shaheen and Srivastava, 1989).This is the second record of the taxon from Western Himalaya.

Type Locality: Sikkim (Eastern Himalaya)

\section{Discussion}

Instituted as Madotheca appendiculata by Franz Stephani in 1910 from the 'type' locality Mussorie in Western Himalaya, the species is currently recognized as Porella densifolia subsp. appendiculata (Steph.) S. Hatt. Kashyap (1932) has described and illustrated the taxon excluding the details of the androecia. The species is large-sized and a robust epiphyte of common occurrence in Western Himalaya. We have made several collections of the taxon but always in a sterile state until recently when we observed the population in a copiously fertile state during the winter months. The species can be distinguished by its golden brown colour, the ventral margin of the leaf-lobe nearly straight (an angle of $80-90^{\circ}$ from the axis), basal appendages of the underleaves and leaflobules being remarkably developed with irregularly lacinulate-toothed appendages and leaves and underleaves not so densely imbricate.
Our observations on the fertile parts of the population of $P$. densifolia subsp. appendiculata (Steph.) S. Hatt. include the presence of numerous androecia on primary or secondary branches in a bipinnately branched male plants, the presence of 6-9 pairs of imbricate and deeply concave male bracts, the presence of a single spherical antheridium in each bract, the presence of large campanulate perianth surrounding 3-8 terminal archegonia.

The second taxon, P. campylophylla var. ptychantha (Mitt.) F. Shaheen \& S.C.Sriv. is based on the 'type' specimen collected by J. D. Hooker from Sikkim in the Eastern Himalaya and instituted as Madotheca ptychantha by William Mitten in 1861. Sinske Hattori (1971) initially made it Porella ptychantha (Mitt.) comb. nov. and later, in 1978, synonimized it with Porella campylophylla (Lehm. \& Lindenb.) Trevis. However, Shaheen and Srivastava (1989) have resurrected the taxon and on the basis of certain notable distinguishing features gave it the status of a variety. The var. ptychantha may be distinguished from the var. campylophylla in having leaf-lobes with blunt and reduced teeth vs. leaf-lobes with sharp teeth, the base of the leaf-lobule being shortly decurrent vs. leaf-lobule and underleaves bases being longly decurrent, widely ovate underleaves vs. oblong ovate underleaves and the crenulate margin of the perianth plicae vs. smooth margin of perianth plicae.

We noted in fertile populations of $P$. campylophylla var. ptychantha (Mitt.) F. Shaheen \& S.C.Sriv. that the androecial branches are longer and always arise from the primary axes; the spherical to ovoid antheridia are 1 or 2 per bract; gynoecia develop on primary and secondary axes both, with one pair of bracts and a single bracteole; perianth 7-8 plicate, crenulate, elliptical; mouth of the perianth is minutely dentate; narrowly incurved ventral margin of the leaf-lobe; simple or branched elaters; and the papillose spores in addition to the varietal features mentioned before.

The fact is that the two species mentioned above are copiously fertile during the intense winter months, at least in this part of the world.

\section{Competing Interests}

The competing interests of the present research paper include (i) the understanding of taxonomy of two Porella species with the aid of additional information on androecia and gynoecia; and (ii) the observation of the fact that the reproductive structures in both taxa appear only when the atmospheric temperature is very low.

\section{Authors' Contributions}

MR conceptualized the idea of the research paper and identified the specimens; PS discussed the ecology of the described taxa and suggested some 
valuable points on their comparison; and, SNS coordinated the work, interpreted the results and drafted the manuscript after thorough discussion with other two authors. All authors read and approved the final manuscript.

\section{Acknowledgements}

We sincerely acknowledge the grant received from UGC for undertaking the present work. We thank Dr. Ashish Kumar Asthana, NBRI, Lucknow for his help in providing literature and Mr. Bishwajit K Kushwaha, Allahabad for his assistance in field and laboratory.

\section{References}

Bapna, K. R. and P. Kachroo. 2000. Hepaticology in IndiaII. Publ. by Himanshu Publications, Udaipur, Delhi. 1-491.

Hattori, S. 1966. In Hara: The Flora of Eastern Himalaya, Results of the Botanical Expeditions to Eastern Himalaya. University of Tokyo, Japan: 501-536.

Hattori, S. 1969. Studies on the Asiatic species of the genus Porella (Hepaticae) II. Journ Hattori Bot Lab 32: 319-359.
Hattori, S. 1971. Studies on the Asiatic species of the genus Porella (Hepaticae) IV. Journ Hattori Bot Lab 34: 411-428.

Hattori, S. 1978. Studies on the Asiatic species of the genus Porella (Hepaticae) VII. A synopsis of Asiatic Hepaticae. Journ Hattori Bot Lab 44: 91-120.

Kashyap, S.R. 1932. Liverworts of the Western Himalayas and the Panjab Plain Part II Publ. by Chronica Botanica, New Delhi 1-137.

Mitten, W. 1861. Hepaticae Indiae orientalis: an enumeration of the Hepaticae of the East Indies. Journ. Proc. Linn. Soc. London 5: 89-128.

Shaheen F. and S. C. Srivastava 1989. Porella campylophylla (Lehm. \& Lindenb.) Trev. complex in India. Geophytology 19(1): 34-48.

Singh S. K. and D. K. Singh. 2006. Contribution to the bryoflora of Great Himalayan National Park, Kullu, Himachal Pradesh IV: Genus Porella (Porellaceae). Geophytology 36 (1\&2): 93-107.

Stephani, F. 1910. Madotheca. In: Species Hepaticarum $4: 241-315$.

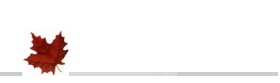

